\title{
Influence of the Spacer Length on the in Vitro Anticancer Activity of Dinuclear Ruthenium-Arene Compounds
}

\author{
Maria-Grazia Mendoza-Ferri,${ }^{\dagger}$ Christian G. Hartinger, ${ }^{*},{ }^{\dagger}$ Rene E. Eichinger, ${ }^{\dagger}$ \\ Natalya Stolyarova,${ }^{\dagger}$ Kay Severin, ${ }^{\star}$ Michael A. Jakupec, ${ }^{\dagger}$ Alexey A. Nazarov, ${ }^{*}{ }^{\dagger}$ and \\ Bernhard K. Keppler \\ Institute of Inorganic Chemistry, University of Vienna, Währinger Strasse 42, A-1090 Vienna, Austria, and \\ Institut des Sciences et Ingénierie Chimiques, Ecole Polytechnique Fédérale de Lausanne,
} CH-1015 Lausanne, Switzerland

Received March 5, 2008

\begin{abstract}
Summary: Water-soluble dinuclear Ru-arene complexes were synthesized and found to exert promising cytotoxic effects in human cancer cells, which could be increased to an $I_{50}$ of 0.29 $\mu M$ by increasing the spacer length between the metal centers. Cytotoxicity could be correlated with lipophilicity ( $\log P$ values) and water solubility. The most potent dinuclear compound, 1,12bis\{chlorido[3-(oxo- $\kappa O)-2$-methyl-4-pyridinonato- $\kappa O 4]\left(\eta^{6}-p-\right.$ isopropyltoluene)ruthenium\}dodecane, is at least 2-3 orders of magnitude more active than the mononuclear analogue

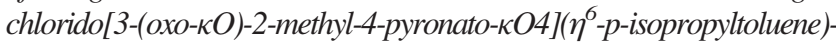
ruthenium.
\end{abstract}

Worldwide, about 7.6 million people die from cancer every year. ${ }^{1}$ Many common cancer types are still untreatable in an advanced stage, or therapy is accompanied by serious side effects and resistance phenomena. The most prominent metalbased antitumor compound, cisplatin (Figure 1), shows curative activity in testicular cancer and significant prolongation of life span in ovarian cancer and to a lesser extent in other tumors. ${ }^{2,3}$

In recent years, ruthenium complexes have attracted interest because they exert their tumor-inhibiting effects by a mode of action different from that of Pt compounds. ${ }^{4}$ Furthermore, they show a favorable toxicity profile in clinical trials: In the case of the ruthenium-indazole complex KP1019 (Figure 1) only very moderate toxicities were observed in a dose range in which proteins were on average loaded with one ruthenium species, which should be sufficient for therapeutic activity. ${ }^{5-7}$ In the case of the $\mathrm{Ru}$ (imidazole)(dimethylsulfoxide) complex NAMI-A (Figure 1) the formation of painful blisters was determined as dose-limiting toxicity. ${ }^{8}$ Binding to plasma proteins as well as reduction of $\mathrm{Ru}^{\mathrm{III}}$ to $\mathrm{Ru}^{\mathrm{II}}$, resulting in an activation of the metal center, is regarded as an important step in the mode of action

\footnotetext{
* Corresponding authors. E-mail: christian.hartinger@univie.ac.at; alex. nazarov@univie.ac.at.

University of Vienna.

Ecole Polytechnique Fédérale de Lausanne.

(1) Huerta, E.; Grey, N. Cancer J. Clin. 2007, 57, 72-74.

(2) Thompson, K. H.; Orvig, C. Dalton Trans. 2006, 761-764.

(3) Kostova, I. Rec. Pat. Anti-Cancer Drug Discovery 2006, 1, 1-22.

(4) Clarke, M. J.; Zhu, F.; Frasca, D. R. Chem. Rev. 1999, 99, 2511-

(5) Groessl, M.; Hartinger, C. G.; Polec-Pawlak, K.; Jarosz, M.; Keppler, B. K. Electrophoresis, DOI 10.1002/elps.200700790.

(6) Pongratz, M.; Schluga, P.; Jakupec, M. A.; Arion, V. B.; Hartinger, C. G.; Allmaier, G.; Keppler, B. K. J. Anal. At. Spectrom. 2004, 19, 46-

(7) Sulyok, M.; Hann, S.; Hartinger, C. G.; Keppler, B. K.; Stingeder, G.; Koellensperger, G. J. Anal. At. Spectrom. 2005, 20, 856-863.

(8) Hartinger, C. G.; Zorbas-Seifried, S.; Jakupec, M. A.; Kynast, B.; Zorbas, H.; Keppler, B. K. J. Inorg. Biochem. 2006, 100, 891-904.
} 2533. 51. of KP1019. ${ }^{9}$ The established Pt anticancer drugs are known to damage DNA, but it is not regarded as the main target of NAMI-A and KP1019. ${ }^{8}$

Furthermore, the use of multinuclear $\mathrm{Pt}$ complexes as chemotherapeutic agents was considered. The trinuclear compound BBR3464 (Figure 1) is 2-3 orders of magnitude more active than cisplatin in cisplatin-resistant cell lines, ${ }^{10}$ but nearly no response was observed in phase II clinical trials. ${ }^{11,12}$ In contrast, multinuclear $\mathrm{Ru}$ complexes with anticancer activity are scarcely explored and only a few dinuclear $\mathrm{Ru}$ complexes with tumor-inhibiting properties are known: complexes with sulfoxide ${ }^{13}$ ethylendiamine, ${ }^{14}$ bisazopyridine,${ }^{15}$ porphyrin, ${ }^{16}$ and ferroceny ${ }^{17}$ ligands as well as NAMI-A analogous complexes ${ }^{18,19}$ exhibit relatively low in vitro activity.

In order to improve the activity of $\mathrm{Ru}(\mathrm{II})-$ arene complexes, which are of current interest as anticancer agents, ${ }^{20-22}$ two Ru moieties were coupled with a varying spacer using maltol-derived bis(3-hydroxy-2-methyl-4-pyridone) ligands (Scheme 1). ${ }^{2,24}$ Very recently, the analogous mononuclear $\mathrm{Ru}-$ maltol complex was

(9) Timerbaev, A. R.; Hartinger, C. G.; Aleksenko, S. S.; Keppler, B. K. Chem. Rev. 2006, 106, 2224-2248.

(10) Manzotti, C.; Pratesi, G.; Menta, E.; Domenico, R. D.; Cavalletti, E.; Fiebig, H. H.; Kelland, L. R.; Farrell, N.; Polizzi, D.; Supino, R.; Pezzoni, G.; Zunino, F. Clin. Cancer Res. 2000, 6, 2626-2634.

(11) Jodrell, D. I.; Evans, T. R. J.; Steward, W.; Cameron, D.; Prendiville, J.; Aschele, C.; Noberasco, C.; Lind, M.; Carmichael, J.; Dobbs, N.; Camboni, G.; Gatti, B.; De Braud, F. Eur. J. Cancer 2004, 40, 18721877.

(12) Hensing, T. A.; Hanna, N. H.; Gillenwater, H. H.; Camboni, M. G.; Allievi, C.; Socinski, M. A. Anti-Cancer Drugs 2006, 17, 697-704.

(13) Huxham, L. A.; Cheu, E. L. S.; Patrick, B. O.; James, B. R. Inorg. Chim. Acta 2003, 352, 238-246.

(14) Chen, H.; Parkinson, J. A.; Novakova, O.; Bella, J.; Wang, F.; Dawson, A.; Gould, R.; Parsons, S.; Brabec, V.; Sadler, P. J. Proc. Natl. Acad. Sci. 2003, 100, 14623-14628.

(15) Hotze, A. C. G.; Kariuki, B. M.; Hannon, M. J. Angew. Chem., Int. Ed. 2006, 45, 4839-4842.

(16) Schmitt, F.; Govindaswamy, P.; Suess-Fink, G.; Ang, W. H.; Dyson, P. J.; Juillerat-Jeanneret, L.; Therrien, B. J. Med. Chem. 2008, 51, 18111816.

(17) Auzias, M.; Therrien, B.; Suess-Fink, G.; Stepnicka, P.; Ang, W. H.; Dyson, P. J. Inorg. Chem. 2008, 47, 578-583.

(18) Alessio, E.; Iengo, E.; Zorzet, S.; Bergamo, A.; Coluccia, M.; Boccarelli, A.; Sava, G. J. Inorg. Biochem. 2000, 79, 173-177.

(19) Bergamo, A.; Stocco, G.; Gava, B.; Cocchietto, M.; Alessio, E.; Serli, B.; Iengo, E.; Sava, G. J. Pharmacol. Exp. Ther. 2003, 305, 725732 .

(20) Yan, Y. K.; Melchart, M.; Habtemariam, A.; Sadler, P. J. Chem. Commun. 2005, 4764-4776.

(21) Ang, W. H.; Dyson, P. J. Eur. J. Inorg. Chem. 2006, 4003-4018. (22) Dyson, P. J.; Sava, G. Dalton Trans. 2006, 1929-1933.

(23) Lang, R.; Polborn, K.; Severin, T.; Severin, K. Inorg. Chim. Acta 1999, 294, 62-67.

(24) Capper, G.; Carter, L. C.; Davies, D. L.; Fawcett, J.; Russell, D. R. J. Chem. Soc., Dalton Trans. 1996, 1399-1403. 


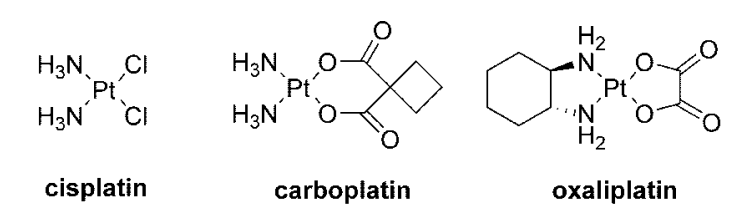

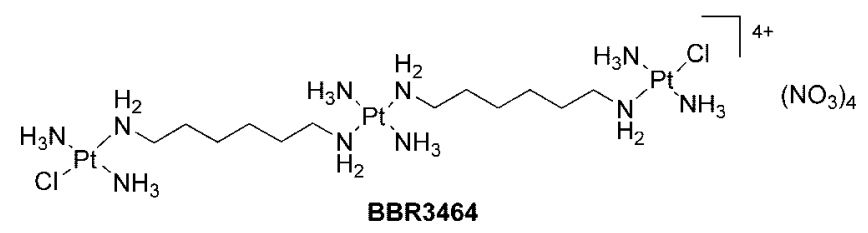

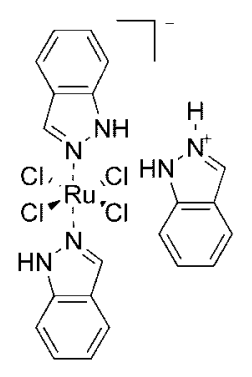

KP1019

NAMI-A

Figure 1. Structures of cisplatin, carboplatin, oxaliplatin, BBR3464, KP1019, and NAMI-A.

Scheme 1. Synthesis of the Dinuclear Ruthenium Complexes $4 a-c(a, n=3, b, n=6 ; c, n=12)$

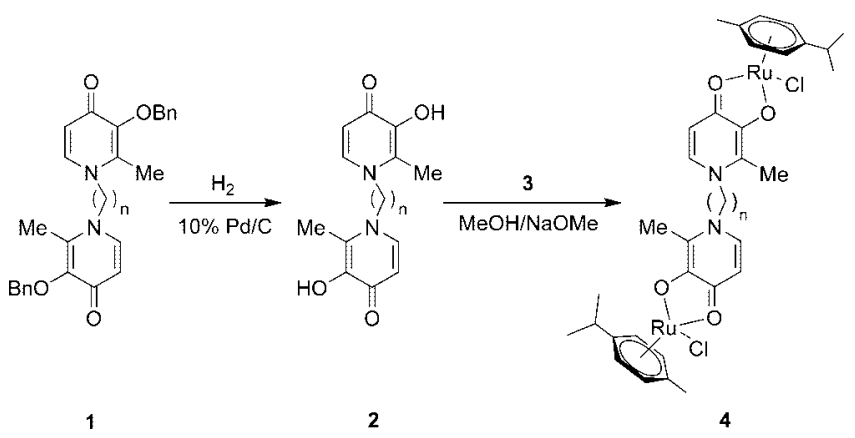

shown to exhibit no in vitro activity up to a concentration of 50 $\mu \mathrm{M}$ in A549 and A2780 cancer cells, and coordination to 9-ethylguanine as a DNA model was established. ${ }^{25}$

The dinuclear $\mathrm{Ru}-$ arene complexes $\mathbf{4 a}-\mathbf{c}$ were obtained by reaction between the bis[dichlorido $\left(\eta^{6}-p\right.$-isopropyltoluene)ruthenium(II)] 3 and deprotonated bis(3-hydroxy-2-methyl-4pyridinon-1-yl)alkanes $\mathbf{2} \mathbf{a}-\mathbf{c}$ (alkane $=$ propane $\mathbf{2} \mathbf{a}$, hexane $\mathbf{2} \mathbf{b}$, dodecane 2c) with yields of $75 \%, 67 \%$, and $45 \%$, respectively (Scheme 1). The ligands were prepared by a modified method of Hider et al., ${ }^{26}$ starting from the naturally available synthone maltol. The benzyl-protected maltol moiety was condensated with primary aliphatic diamines with varying chain lengths of three, six, and $12 \mathrm{CH}_{2}$ groups, and the products were isolated as $\mathrm{HCl}$-free compounds (in contrast to previous reports ${ }^{26}$ ) by slow crystallization from the reaction mixture or by column chromatography on silica gel. Finally, ligands $\mathbf{2 a - c}$ were obtained by catalytic hydrogenolysis of the benzyl group.

(25) Peacock, A. F. A.; Melchart, M.; Deeth, R. J.; Habtemariam, A.; Parsons, S.; Sadler, P. J. Chem.-Eur. J. 2007, 13, 2601-2613.

(26) Hider, R. C.; Kontoghiorghes, G.; Silver, J.; Stockham, M. A. Hydroxypyridinone derivatives and pharmaceutical compositions containing them. EP 84-306438, 1985. Mendoza-Ferri, M. G.; Hartinger, C. G.; Nazarov, A. A.; Kandioller, W.; Severin, K.; Keppler, B. K. Appl. Organomet. Chem. 2008, 22, 326-332.

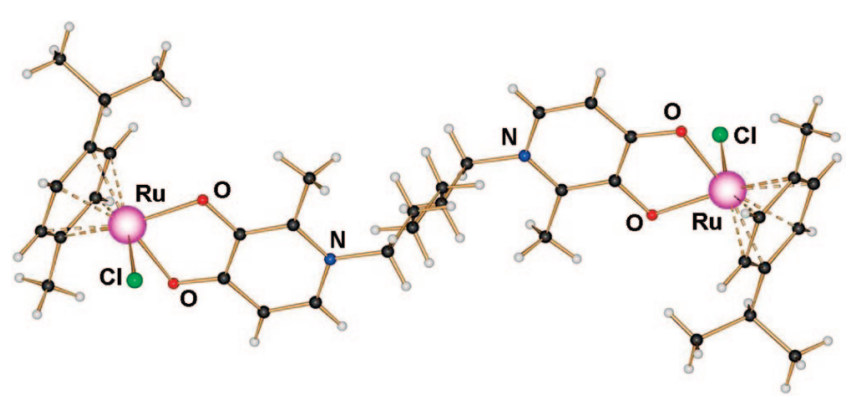

Figure 2. Graphical representation of the molecular structure of the $(R, R)$-enantiomer of complex $\mathbf{4} \mathbf{b}$ in the crystal.

Table 1. Comparison of Selected Bond Lengths of $4 \mathrm{~b}$ and Chlorido[3-(oxo- $\kappa O)$-2-methyl-4-pyronato- $\kappa O 4]\left(\eta^{6}\right.$-p-isopropyltoluene)ruthenium(II) (5)

\begin{tabular}{lcc}
\hline & \multicolumn{2}{c}{ bond lengths $(\AA) /$ angles $(\mathrm{deg})$} \\
\cline { 2 - 3 } & \multicolumn{1}{c}{$\mathbf{4 b}$} & $\mathbf{5}^{a}$ \\
\hline $\mathrm{Ru}-\mathrm{Cl}$ & $2.4186(10)$ & $2.4329(5)$ \\
$\mathrm{Ru}-\mathrm{O} 1$ & $2.101(3)$ & $2.1035(13)$ \\
$\mathrm{Ru}-\mathrm{O} 2$ & $2.074(3)$ & $2.0901(13)$ \\
$\mathrm{O} 1-\mathrm{Ru}-\mathrm{O} 2$ & $79.63(11)$ & $78.79(5)$ \\
$\mathrm{O} 1-\mathrm{Ru}-\mathrm{Cl}$ & $83.90(8)$ & $83.42(4)$ \\
$\mathrm{Cl}-\mathrm{Ru}-\mathrm{O} 2$ & $85.11(8)$ & $85.89(4)$ \\
${ }^{a}$ From Peacock et al. & &
\end{tabular}

The complexes were characterized spectroscopically by ${ }^{1} \mathrm{H}$ and ${ }^{13} \mathrm{C}$ NMR and electrospray ionization (ESI) mass spectrometry. The results corroborate the expected structure: Coordination of the metal center to the ligand resulted in an upfield shift of approximately $0.2 \mathrm{ppm}$ for the $\mathrm{N}-\mathrm{CH}$ proton (at about $7.4 \mathrm{ppm}$ ). In ESI mass spectra in both water and methanol, the most abundant peaks were assigned to the doubly charged $[\mathrm{M}-2 \mathrm{Cl}]^{2+}$ ions. Furthermore, $[\mathrm{M}-\mathrm{Cl}]^{+}$and $[\mathrm{M}+\mathrm{Na}]^{+}$ions were detected, containing the highly characteristic isotope pattern for ruthenium and $\mathrm{Ru}-\mathrm{Cl}$ species, respectively.

The molecular structure of $\mathbf{4 b} \cdot \mathrm{CHCl}_{3}$ was determined by X-ray diffraction analysis (Figure 2). The metal centers adopt the pseudooctahedral "piano-stool" geometry, with the $\pi$-bound arene being the seat and the $\sigma$-bound chlorido and $O, O$-chelate occupying the chair's legs. The $\mathrm{Ru}-\mathrm{C}$ bond lengths are similar to those reported for chlorido[3-(oxo- $\kappa O)$-2-methyl-4-pyridinonato- $\kappa O 4]\left(\eta^{6}-p\right.$-isopropyltoluene)ruthenium(II) $(\mathbf{5}),{ }^{25}$ while the $\mathrm{Ru}-\mathrm{O}$ and the $\mathrm{Ru}-\mathrm{Cl}$ bonds are slightly contracted in $\mathbf{4 b}$ (Table 1 ).

The complexes have two stereogenic ruthenium centers, leading to a mixture of diastereoisomers. Due to the presence of an axis of symmetry in the molecules, only one set of signals is observable in the ${ }^{1} \mathrm{H}$ NMR spectra. In order to study the epimerization of the dinuclear complexes, ${ }^{1} \mathrm{H}$ NMR measurements were performed for $\mathbf{4 b}$ in polar and nonpolar solvents at room temperature (Figure 3). In the polar solvents $\mathrm{D}_{2} \mathrm{O}$ and $\mathrm{CD}_{3} \mathrm{OD}$, the epimerization takes place very quickly, and thus only two doublets were detected for the aromatic protons of the arene group and a single signal for the isopropyl groups as well as a well-defined triplet for the $\mathrm{CH}_{2}-\mathrm{N}$ group (Figures $3 \mathrm{a}$ and $3 \mathrm{~b}$ ). These observations may be due to a fast inversion of the metal center. ${ }^{27}$ In contrast, spectra in $\mathrm{CDCl}_{3}$ show four doublets for the aromatic protons of the arene group and two signals for the isopropyl groups as well as two broad multiplets for the $\mathrm{CH}_{2}-\mathrm{N}$ groups (Figure $3 \mathrm{c}$ ). This is in accordance with previously reported results for similar mononuclear complexes. $^{23}$

(27) Abbott, A. P.; Capper, G.; Davies, D. L.; Fawcett, J.; Russell, D. R. J. Chem. Soc., Dalton Trans. 1995, 3709-3713. 

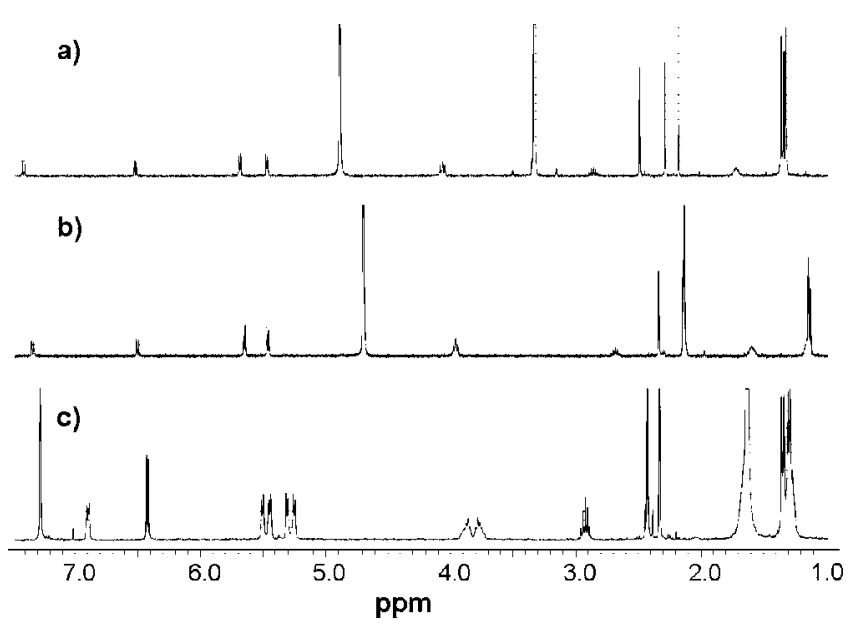

Figure 3. ${ }^{1} \mathrm{H}$ NMR spectra of $\mathbf{4 b}$ in (a) $\mathrm{CD}_{3} \mathrm{OD}$, (b) $\mathrm{D}_{2} \mathrm{O}$, and (c) $\mathrm{CDCl}_{3}$.

Table 2. $\mathrm{IC}_{50}$ Values of the Complexes $4 \mathrm{a}-\mathrm{c}$ in A2780 and SW480 Cells in Comparison to the Pt Complexes Cisplatin, Oxaliplatin, Carboplatin, and BBR3464 and the Ru Compounds KP1019 and the 4a-c Analogous Mononuclear Maltol Complex 5

\begin{tabular}{lll}
\hline & \multicolumn{2}{c}{$\mathrm{IC}_{50} / \mu \mathrm{M}$} \\
\cline { 2 - 3 } compound & \multicolumn{1}{c}{$\mathrm{A} 2780$} & $\mathrm{SW} 480$ \\
\hline $\mathbf{4 a}$ & $25 \pm 2$ & $62 \pm 14$ \\
$\mathbf{4 b}$ & $30 \pm 6$ & $26 \pm 8$ \\
$\mathbf{4 c}$ & $1.5 \pm 0.3$ & $0.29 \pm 0.05$ \\
$\mathbf{5}$ & $>100^{25}$ & $>100$ \\
cisplatin & $0.33 \pm 0.04^{28}$ & $4.5 \pm 1.7$ \\
carboplatin & & $61 \pm 10$ \\
oxaliplatin & $0.40 \pm 0.12^{28}$ & $0.30 \pm 0.08$ \\
BBR3464 & $0.01^{29}$ & \\
KP1019 & & $49 \pm 11$
\end{tabular}

The $50 \%$ inhibitory concentrations $\left(\mathrm{IC}_{50}\right)$ of the new complexes $\mathbf{4 a}-\mathbf{c}$ have been determined in human ovarian carcinoma (A2780) and colon adenocarcinoma (SW480) cells. $\mathrm{IC}_{50}$ values decrease in the cell line SW480 from 62 to 26 and $0.29 \mu \mathrm{M}$ with increasing chain length of the spacer from three to six and $12 \mathrm{CH}_{2}$ groups (Table 2, Figure 4). In A2780 cells, $\mathbf{4 a}$ and $\mathbf{4 b}$ show similar activity, but again $\mathbf{4} \mathbf{c}$ is the most potent compound. $\mathbf{4} \mathbf{c}$ is 1 order of magnitude more active than cisplatin and equally active as oxaliplatin in the cell line SW480 and, compared with data from the literature, ${ }^{28}$ only $4-5$ times less cytotoxic than cisplatin $\left(\mathrm{IC}_{50}\right.$ $=0.33 \mu \mathrm{M})$ and oxaliplatin $\left(\mathrm{IC}_{50}=0.40 \mu \mathrm{M}\right)$ in the platinumsensitive cell line A2780. Furthermore, $\mathbf{4 c}$ is 170 times more

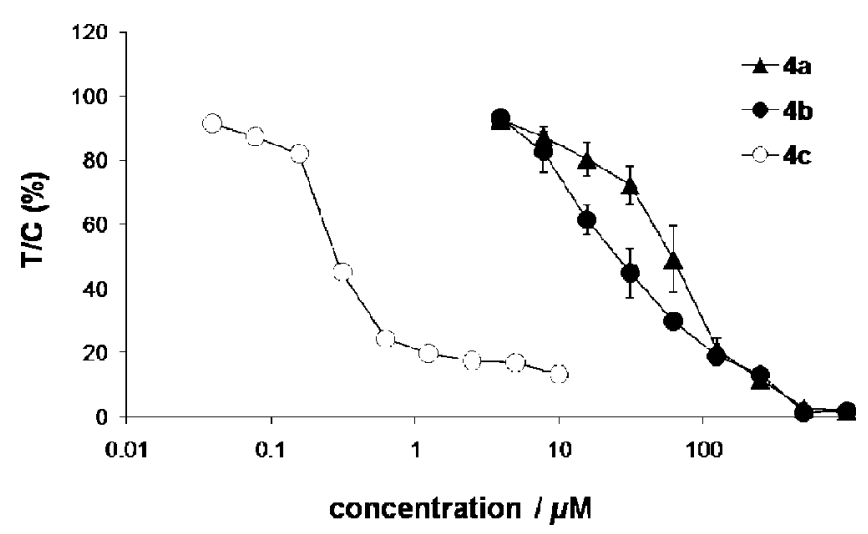

Figure 4. Concentration-effect curves of dinuclear Ru(II)-arene complexes $\mathbf{4 a}-\mathbf{c}$, obtained by the MTT assay in SW480 cells. Values are means \pm standard deviations from at least three independent experiments. cytotoxic in SW480 cells than the mononuclear Ru(III) complex KP1019, which is currently being studied in clinical trials. Although methodological differences have to be considered, $\mathbf{4 c}$ is 2 orders of magnitude less cytotoxic than the trinuclear platinum complex BBR3464 (A2780: $\left.\mathrm{IC}_{50}=0.01 \mu \mathrm{M}\right) \cdot{ }^{29}$ However, coupling three Pt centers in BBR3464 increases the cytotoxicity only by a factor of approximately 30 , whereas the Ru complexes presented here are active only when two metals centers are coupled; that is, the mononuclear analogue is not cytotoxic.

The spacer-length-dependent cytotoxicity in cancer cells implicates a correlation with the lipophilicity of the compounds, which is an important factor for anticancer drugs, since hydrophobic compounds can cross cell membranes easier than hydrophilic ones. ${ }^{30}$ The lipophilic character of $\mathbf{4 a}-\mathbf{c}$ was investigated by determination of the $n$-octanol/water partition coefficient, $\log P$, applying the shake flask method. ${ }^{31}$ Ruthenium contents in the aqueous and octanol phases were quantified by ICP-MS and UV/ vis, respectively, and both methods lead to essentially identical results. $\log P$ values in the range from -1.33 to -0.56 were obtained for the dinuclear compounds and correlate with the length of the spacer linking the pyridinone moieties. The solubility of the dinuclear compounds in water reflects the $n$-octanol/water partition coefficients. With increasing chain length of the complexes from three to six and $12 \mathrm{CH}_{2}$ groups, the solubility in water decreases from about 13.4 to 3.4 and $0.5 \mathrm{mM}$, respectively, also correlating with the in vitro activity.

Summarizing, coupling more than one metal center with the aim of improving the anticancer activity of $\mathrm{Ru}(\mathrm{II})$-arene metallodrugs led to the development of complexes with high activity in human tumor cell lines. Notably, not only an additive effect of the analogous mononuclear complexes but a synergistic effect in two cell lines was observed, being of extraordinary dimension in SW480 cells for Ru compounds. For the series of dinuclear compounds, a spacer-length-dependent order of in vitro activity was found, allowing modulation of both anticancer activity and lipophilicity. However, the mode of action is not absolutely clear yet, and several targets, including DNA but also proteins, are conceivable.

Acknowledgment. We thank the University of Vienna, the Hochschuljubiläumsstiftung Vienna, the Theodor-Körner-Fonds, the Austrian Council for Research and Technology Development, the FFG-Austrian Research Promotion Agency (Project FA 526003), the FWF-Austrian Science Fund (Schrödinger Fellowship J2613-N19 [C.G.H.] and project P18123-N11), the EPFL (C.G.H.), and COST D20 and D39 for financial support. We gratefully acknowledge Dr. Markus Galanski for recording the NMR spectra and Prof. Vladimir Arion for collecting and refining the X-ray diffraction data.

Supporting Information Available: Experimental details for synthesis, analytical characterization, X-ray diffraction data, and (bio)analytical studies. CCDC 645988 contains the supplementary crystallographic data for this paper. This material is available free of charge via the Internet at http://pubs.acs.org.

\section{OM800207T}

(28) Messori, L.; Marcon, G.; Cinellu, M. A.; Coronnello, M.; Mini, E.; Gabbiani, C.; Orioli, P. Bioorg. Med. Chem. 2004, 12, 6039-6043.

(29) Sharp, S. Y.; O’Neill, C. F.; Rogers, P.; Boxall, F. E.; Kelland, L. R. Eur. J. Cancer 2002, 38, 2309-2315.

(30) Romerosa, A.; Campos-Malpartida, T.; Lidrissi, C.; Saoud, M.; Serrano-Ruiz, M.; Peruzzini, M.; Garrido-Cardenas, J. A.; Garcia-Maroto, F. Inorg. Chem. 2006, 45, 1289-1298.

(31) OECD, Guidelines for Testing of Chemicals. In OECD; Paris, 1995; Vol. 107. 